\title{
Effects of Tea Residue Biochar on Phosphorus Adsorption-Desorption in Soil
}

\author{
Jin-Jin Zhao", , Xian-Huai Huang, ${ }^{1,2}$, Lu-Lu Hua ${ }^{1,2}$, Sai-Sai Zhou ${ }^{1,2}$, \\ Wei Jiang ${ }^{1,2}$, Yu-Chao Tang ${ }^{1,2}$, Jing Qian ${ }^{1,2 *}$ \\ ${ }^{1}$ Anhui Jianzhu University, Hefei 230601, China \\ ${ }^{2}$ Anhui Provincial Key Laboratory of Environmental Pollution Control and Resource Reuse, Hefei 230061, China
}

Received: 17 September 2021

Accepted: 26 October 2021

\begin{abstract}
Adsorption and desorption of phosphorus (P) by biochar affect the effect of soil phosphorus fixation. In order to investigate the effect of tea residue biochar on the adsorption and desorption of phosphorus in tea garden soil and reduce the leaching loss of phosphorus in soil, the adsorption and desorption characteristics of phosphorus in tea garden soil were studied by equilibrium adsorption method. In the simulated culture experiment, biochar was prepared at different pyrolysis temperatures $\left(400^{\circ} \mathrm{C}, 500^{\circ} \mathrm{C}, 600^{\circ} \mathrm{C}\right)$ and added at different concentrations $(0.25 \%, 0.50 \%, 1.0 \%, 2.0 \%)$. Results showed that the $\mathrm{P}$ adsorption capacity in tea garden soil treated by three types of biochar trends was $\mathrm{BC} 400>\mathrm{BC} 500>\mathrm{BC} 600$, the $\mathrm{BC} 400$ treatment with $1.0 \%$ showed the best results. The $\mathrm{P}$ adsorption process by soil, dominated by monolayer adsorption, reached a significant level by matching the Langmuir equation $\left(0.95<\mathrm{R}^{2}<0.98\right)$. On the contrary, the application of tea residue biochar to soil significantly reduced the soil $\mathrm{P}$ desorption. In addition, environmental factors (temperature and $\mathrm{pH}$ ) significantly affected on $\mathrm{P}$ adsorption process $(\mathrm{P}<0.05)$. The current results suggested that tea residue biomass carbon can improve the soil's ability of fixation to phosphorus and reduce the leaching of phosphorus.
\end{abstract}

Keywords: adsorption-desorption, biochar, phosphorus, pyrolysis temperature, tea residue

\section{Introduction}

As Phosphorus (P) is an important nutrient element in plants, it is a major limiting factor of water eutrophication. Most insoluble $\mathrm{P}$ compounds exist in soil [1] and the utilization rate of $\mathrm{P}$ fertilizer in soil is generally less than $20 \%$ [2]. $\mathrm{P}$ is a non-renewable resource [3]. Most of $\mathrm{P}$ exists in a fixed state after it

*e-mail: 594077072@qq.com is applied to the soil, making it difficult for plants to use [4]. In addition, the excessive application and low utilization rate of $\mathrm{P}$ fertilizer leads to significant $\mathrm{P}$ accumulation in the soil, increasing the risk of $\mathrm{P}$ loss in the soil and becomes one of the primary causes of water eutrophication. The loss degree of soil phosphorus depends on climate and terrain [5], air quality [6], fertilization status, slope, crop coverage, soil conditions, human activities [7] and other factors. The addition of soil biochar not only solves the problems of unreasonable disposal of agricultural wastes and environmental pollution [8], but also increases 
the content of soil organic matter, reduces the toxicity of soil heavy metals [9], promotes the activity of enzymes and improves the level of soil fertility [10]. It is of great significance to improve the soil structure and reduce the pollution of soil and water loss to the ecological environment [11]. Therefore, improving the adsorption capacity of soil to phosphorus is of great significance to the study of soil phosphorus management.

Biochar is a highly aromatic material with a high carbon content, decomposed by straw, rice husk, sawdust, fallen leaves, and other plant fiber wastes and animal manure at high temperatures in the case of hypoxia or hypoxia [12]. Biochar has broad application prospects [13] in soil improvement, pollution control, carbon sequestration [14] and emission reduction [15] due to its unique porous structure, large specific surface area [16], negative charge [17] and surface functional groups [18]. Previous research has shown that biochar can directly release $\mathrm{P}$, improve the available $\mathrm{P}$ concentration in acidic soil [19], or indirectly affect the release of $\mathrm{P}$ by changing soil $\mathrm{pH}$ and organic matter content [20]. However, due to the complexity and variability of soil $\mathrm{P}$ adsorption characteristics [21], the research results on the $\mathrm{P}$ adsorption mechanism of biochar on acid soil are still controversial. Rashmi et al. [22] pointed out that the biochar addition can increase the calcium content in soil, thus promoting the adsorption of $\mathrm{P}$ in acidic soil. In contrast, Mukherjee S. et al. [23] revealed that the soil adsorption sites were occupied by $\mathrm{P}$ released by biochar, therefore, the addition of biochar would reduce the adsorption of P. Although the application of biochar prepared from different raw materials to the soil affect the $\mathrm{P}$ adsorption process, the adsorption results differ [24]. In addition, studies have found that the $\mathrm{pH}$, ash content and available $\mathrm{P}$ content of biochar prepared at high temperatures are significantly higher than those of low-temperature carbon [25]. Therefore, the type and temperature of biochar affect the adsorption-desorption of soil phosphorus.

Anhui province is a famous tea-producing province in China [26], and its tea production ranks third in China. In recent years, due to the increasing tea beverage markets and the continuous development of the tea industry, a significant number of tea dregs have been produced. In this context, the main objective of this study was to evaluate the adsorption-desorption of $\mathrm{P}$ in soil by biochar. The tea residue was used as a carbon source to synthesize biochar by pyrolysis. Combined with environmental factors, the biochar prepared at different pyrolysis temperatures was taken as the research object, Linear regression, root mean square error, mean absolute error and $\mathrm{R}^{2}$ were used to evaluate and analyze the data [27], and the influence of its input into tea garden soil on the adsorptiondesorption performance of $\mathrm{P}$ on soil was discussed, which providing a theoretical basis for the resource utilization of tea residue and the improvement of soil $\mathrm{P}$ utilization efficiency.

\section{Material and Methods}

\section{Experiment Materials}

The tested soil was a typical tea garden soil (yellow brown soil), which was collected from the tea garden in Tongcheng County, China (N 31 522', E 116 533'). The region has a subtropical monsoon humid climate with an average annual temperature about $17^{\circ} \mathrm{C}$. The average annual precipitation of $1300 \mathrm{~mm}-1500 \mathrm{~mm}$. It has a mild climate, moderate rainfall, less frost and less snow and four distinct seasons. Soil samples were collected from the $0-20 \mathrm{~cm}$ topsoil layer, which were removed stones and roots, air-dried, ground and passed through a 2-mm sieve. The basic physical and chemical properties of each soil sample was determined according to the standard soil test method [28]. The concentration of total $\mathrm{P}$ was $72 \pm 3 \mathrm{mg} / \mathrm{L}$. The basic physical and chemical properties of the soil in this area are as follows: the $\mathrm{pH}$ of the soil is 5.16, the concentration of CEC is $37.72 \mathrm{cmol} \cdot \mathrm{L}^{-1}$, the content of organic matter is $19.14 \mathrm{~g} / \mathrm{kg}$, the content of total $\mathrm{N}$ is $6.39 \mathrm{~g} / \mathrm{kg}$, the content of Total $\mathrm{P}$ is $806.7 \mathrm{mg} / \mathrm{kg}$, the content of available $\mathrm{P}$ is $2.9 \mathrm{mg} / \mathrm{kg}$, and the content of available potassium is $256 \mathrm{mg} / \mathrm{kg}$.

The waste tea dregs were collected from Huangshan tea factory in Anhui province. After removing the large particles impurities, the tea residue was ground to $2 \mathrm{~mm}$ sieve after air drying and put into use. The biomass carbon was prepared by oxygen limiting pyrolysis in muffle furnace. The $\mathrm{N}_{2}$ was introduced as the protective gas, and the temperature was heated up to different temperatures $\left(400^{\circ} \mathrm{C}, 500^{\circ} \mathrm{C}, 600^{\circ} \mathrm{C}\right)$ seperately $\left(10^{\circ} \mathrm{C} / \mathrm{min}\right)$ and hold constant for $2 \mathrm{~h}$ of carbonation. After carbonization, cool to normal temperature, take out and grind 100 mesh sieve. The biomass carbon prepared at the pyrolysis temperature of $400^{\circ} \mathrm{C}, 500^{\circ} \mathrm{C}$ and $600^{\circ} \mathrm{C}$ was denoted by $\mathrm{BC} 400, \mathrm{BC} 500$ and $\mathrm{BC} 600$. The $\mathrm{pH}$ of biomass carbon was determined by the $\mathrm{pH}$ analysis of the composite $\mathrm{pH}$ electrode phs-3c after stirring at $25^{\circ} \mathrm{C}$ for $30 \mathrm{~min}$. The CEC of biomass carbon was exchanged by ammonium acetate. Total $\mathrm{N}$ and organic $\mathrm{C}$ were determined by elemental analyzer (LECO Corp ration, St. Joseph, MI, USA). Total P was determined by molybdenum blue spectrophotometer (BioTek, epoch2, winooski, Vermont, USA). The results of the above basic physicochemical properties were mean values \pm standard deviation of duplicate measurements (Table 1).

\section{Culture Experiment}

The mixture of soil and biochar (biochar/soil mass ratio is $0.25 \%, 0.5 \%, 1.0 \%, 2.0 \%$ ) passing $2 \mathrm{~mm}$ sieve was put into the culture bottle and the water content was adjusted to $70 \%$ of the field water capacity. The surface of the sample was covered with porous plastic film and the culture experiment was carried out in a closed incubator with a constant temperature 
Table 1. Basic physical and chemical properties of biochar.

\begin{tabular}{|c|c|c|c|c|c|c|}
\hline Sample & $\mathrm{pH}$ & CEC $\left(\mathrm{cmol} \cdot \mathrm{L}^{-1}\right)$ & Total N $\left(\mathrm{g} / \mathrm{kg}^{-1}\right)$ & Total P $\left(\mathrm{g} / \mathrm{kg}^{-1}\right)$ & Organic C $\left(\mathrm{g} / \mathrm{kg}^{-1}\right)$ & $\mathrm{BET}\left(\mathrm{m}^{2} / \mathrm{g}\right)$ \\
\hline BC400 & $7.87 \mathrm{a}$ & $34.89 \mathrm{a}$ & $38.15 \mathrm{a}$ & $4.34 \mathrm{c}$ & $643 \mathrm{c}$ & $1.156 \mathrm{c}$ \\
\hline BC500 & $7.91 \mathrm{a}$ & $23.57 \mathrm{~b}$ & $36.60 \mathrm{~b}$ & $5.06 \mathrm{~b}$ & $658 \mathrm{~b}$ & $2.298 \mathrm{~b}$ \\
\hline BC600 & $7.97 \mathrm{a}$ & $21.82 \mathrm{c}$ & $32.61 \mathrm{c}$ & $5.86 \mathrm{a}$ & $709 \mathrm{a}$ & $3.481 \mathrm{a}$ \\
\hline
\end{tabular}

Note: Different uppercase letters indicate statistical significance at the $P<0.05$ using Duncan's multiple range test.

of $25^{\circ} \mathrm{C}$ (from November 2020). Deionized water was added every 3 days to maintain the initial water content, after 40 days, and air dry it, pass through $0.25 \mathrm{~mm}$ sieve for standby. There were 13 treatments in total, and each treatment was set to repeat 3 times.

\section{Isothermal Adsorption-Resorption Tests}

In phosphorus sorption/desorption experiments, the $2.00 \mathrm{~g}$ soil and biochar mixture samples were placed in $50 \mathrm{~mL}$ centrifuge tubes and added into $20 \mathrm{~mL}$ $\mathrm{KH}_{2} \mathrm{PO}_{4}$ solution with concentration of $0,20,40,60,80$, $100,120,160$ and $200 \mathrm{mg} / \mathrm{L}$, according to $\mathrm{m}$ (sample): $\mathrm{v}$ (solution) $=1: 20.0 .01 \mathrm{~mol} / \mathrm{L} \mathrm{KCl}$ solution was used as background electrolyte and 3 drops of chloroform was added to inhibit microbial activity. The centrifuge tube was oscillated at $25^{\circ} \mathrm{C}$ for 24 hours, then centrifuged at $5000 \mathrm{rpm}$ for $10 \mathrm{~min}$. The supernatant was immediately filtered through syringe filter with aperture of $0.45 \mu \mathrm{m}$.

After the completion of the adsorption experiment, take the samples with the above concentration of 20, 100 and $200 \mathrm{mg} / \mathrm{L}$, added $25 \mathrm{~mL} 0.01 \mathrm{~mol} / \mathrm{L} \mathrm{KCl}$ solution into the centrifuge tube to remove the supernatant, stir evenly and oscillate for $1 \mathrm{~h}$. After equilibration at $25^{\circ} \mathrm{C}$ for 24 hours, centrifuged at $5000 \mathrm{rpm}$ for $10 \mathrm{~min}$, the supernatant was immediately filtered through syringe filter with aperture of $0.45 \mu \mathrm{m}$. Take the filtered solution for testing.

\section{Evaluation of Environmental Factors Affecting P Adsorption Behavior}

In order to study the effect of temperature on the $\mathrm{P}$ adsorption in soil, isothermal adsorption experiments were carried out at $288 \mathrm{k}, 298 \mathrm{~K}$ and $308 \mathrm{k}$, which were denoted by $\mathrm{T}_{1}, \mathrm{~T}_{2}$ and $\mathrm{T}_{3}$. Before the test, adjusted the initial $\mathrm{pH}$ of $\mathrm{P}$ containing solution to 4.0 with $0.01 \mathrm{~mol} / \mathrm{L} \mathrm{HCl}$ or $\mathrm{NaOH}$ solution $4.0 \pm 0.2,7.0 \pm 0.2$ and $9 \pm 0.2$. The effect of $\mathrm{pH}$ of initial solution on $\mathrm{P}$ adsorption by soil was tested, which were denoted by $\mathrm{pH}=4, \mathrm{pH}=7$ and $\mathrm{pH}=9$. Each group was repeated 3 times.

\section{Data Analysis}

The absorption capacity of biochar (Q, $\mathrm{mg} / \mathrm{g})$ is calculated by Equation (1):

$$
Q=\frac{\left(C_{0}-C_{\mathrm{e}}\right) \times V}{M}
$$

Where $\mathrm{Q}$ is the adsorption of capacity $(\mathrm{mg} / \mathrm{g}) ; \mathrm{C}_{0}$ is the concentration of initial solution $(\mathrm{mg} / \mathrm{L}) ; \mathrm{C}_{\mathrm{e}}$ is the concentration of adsorption equilibrium solution $(\mathrm{mg} / \mathrm{L}) ; \mathrm{V}$ is the volume of initial adsorption solution (L); $\mathrm{M}$ is the mass of the sample (g).

The adsorption process of $\mathrm{P}$ by tea garden soil and tea garden soil with biochar was fitted by Langmuir model (2) and Freundlich model (3).

Langmuir model: $Q=\frac{\left(K_{L} C_{e} Q_{\max }\right)}{\left(1+K_{L} C_{e}\right)}$

and

Freundlich model: $Q=K_{F} C_{\mathrm{e}}^{1 / n}$

Where $K_{L}$ is the equilibrium constant of Langmuir adsorption model; $\mathrm{Q}_{\max }$ is the maximum adsorption capacity $(\mathrm{mg} / \mathrm{g}) ; \mathrm{K}_{\mathrm{F}}$ is the empirical coefficient of Freundlich adsorption model; $1 / \mathrm{n}$ is a dimensionless coefficient related to the adsorption strength.

The desorption capacity of biochar $(\mathrm{Q}, \mathrm{mg} / \mathrm{g})$ is calculated by Equation (4):

$$
Q_{\mathrm{n}}=\frac{\left(V_{a} C_{a}-V_{e} C_{\mathrm{e}}\right)}{M}
$$

Where $\mathrm{Q}_{\mathrm{n}}$ is the desorption amount $(\mathrm{mg} / \mathrm{g}) ; \mathrm{V}_{\mathrm{a}}$ is the volume of desorption equilibrium solution (L); $\mathrm{C}_{\mathrm{a}}$ is the concentration of desorption equilibrium solution $(\mathrm{mg} / \mathrm{L}) ; \mathrm{V}_{\mathrm{e}}$ is the volume of residual sample of adsorption equilibrium solution (L); $\mathrm{C}_{e}$ is the concentration of adsorption equilibrium solution $(\mathrm{mg} / \mathrm{L})$; $\mathrm{M}$ is the mass of the sample $(\mathrm{g})$ (The value of $\mathrm{V}_{\mathrm{e}}$ can be regarded as equal to the weight of the sample residual solution).

To gain a better understanding of the phosphate adsorption process, the adsorption thermodynamics analysis was further explored, as indicated below.

$$
\Delta G=-R T \ln K_{m}
$$




$$
\begin{gathered}
\Delta S=\frac{\Delta H-\Delta G}{T} \\
Q_{\mathrm{m}}=n R T
\end{gathered}
$$

Where $\Delta G$ is Gibbs free energy $(\mathrm{kJ} / \mathrm{mol}) ; \Delta S$ is the entropy change of adsorption $(\mathrm{J} / \mathrm{mol}) ; \Delta H$ is the enthalpy change of isosteric adsorption $(\mathrm{kJ} / \mathrm{mol})$; $\mathrm{Q}_{\mathrm{m}}$ is the adsorption heat $(\mathrm{J} / \mathrm{mol}) ; \mathrm{T}$ is the absolute temperature; $\mathrm{R}$ is the ideal gas constant (8.314); $\mathrm{K}_{\mathrm{m}}$ is the thermodynamic equilibrium constant, which is transformed from the $\mathrm{K}$ value in Langmuir equation and $\mathrm{n}$ is the value in Freundlich equation.

\section{Analytical Methods}

The morphology and size of biochar was observed by SEM (JSM-7600F). The crystal structure of biochar was analyzed by X-ray diffraction (XRD Smartlab $9 \mathrm{kw}$ ). The surface functional groups of biochar were determined by Fourier transform infrared spectroscopy (FTIR) (Nicolet is10). In the isothermal adsorption test, the supernatant was poured out and filtered, and then determined by ascorbic acid phosphomolybdate blue colorimetry and ultraviolet spectrophotometer.

\section{Statistical Analysis}

Data processing and analysis was performed with Microsoft Office Excel 2010 (Microsoft, Raymond, Washington, USA). The $\mathrm{P}$ adsorption curve was plotted by originpro8.0 (Originlab company, Northampton, Massachusetts, USA). PASW statistics 18 (SPSS, Chicago, Illinois, USA) was used for statistical analysis. The average was calculated from three replicates of each experiment. The statistical significance of difference was conducted through the analysis of variance (ANOVA). The level of accepted statistical significance was $\mathrm{P}<0.05$. According to the Michelin guideline scale, $\mathrm{P}<0.05^{*}$ was statistically significant, $\mathrm{P}<0.01 * *$ was highly statistically significant.

\section{Results and Discussion}

\section{Characterization of Biochar}

Biochar is composed of irregular plates and particles of different sizes [29]. As shown in Fig. 1 under a scanning electron microscope magnification of $5000 \times$ the structure of the tea residue biochar changes depending on the pyrolysis preparation temperatures. The pore distribution of biochar prepared at $400^{\circ} \mathrm{C}$ (BC400) was relatively disordered, and the surface texture was rough and uneven. With an increase in temperature to $500^{\circ} \mathrm{C}(\mathrm{BC} 500)$, the volatile components of biochar cracked and precipitated, and the biochar began to fracture; When the temperature rose to $600^{\circ} \mathrm{C}$ (BC600), the fracture phenomenon became more obvious and the fracture delamination phenomenon appeared.

Fourier transform infrared spectroscopy (Fig. 2) showed that the aliphatic unsaturated $\mathrm{C}-\mathrm{H}$ stretching vibration absorption peaks appeared at $3432 \mathrm{~cm}^{-1}$ for biochar with different pyrolysis temperatures, Aliphatic saturated $\mathrm{C}-\mathrm{H}$ stretching vibration absorption peaks appeared at $2920 \mathrm{~cm}^{-1}$ and $2845 \mathrm{~cm}^{-1}$, and the $\mathrm{C}=\mathrm{C}$ stretching vibration absorption peak of the aromatic skeleton appeared at the wave number of $1612 \mathrm{~cm}^{-1}$. This indicated that the three biochars had similar molecular structure characteristics. BC400 biochar exhibited aliphatic $\mathrm{C}-\mathrm{H}$ deformation vibration at a wavelength of $1312 \mathrm{~cm}^{-1}$, C-O-C stretching vibration of alcohols and ethers, and $\mathrm{C}-\mathrm{O}$ stretching vibration of aromatic esters were observed at a wavelength $1114-13120 \mathrm{~cm}^{-1}$. The $\mathrm{C}-\mathrm{H}$ bending vibration peak was observed at wavelength of $781 \mathrm{~cm}^{-1}$. This indicated a high concentration of aromatic components. a)

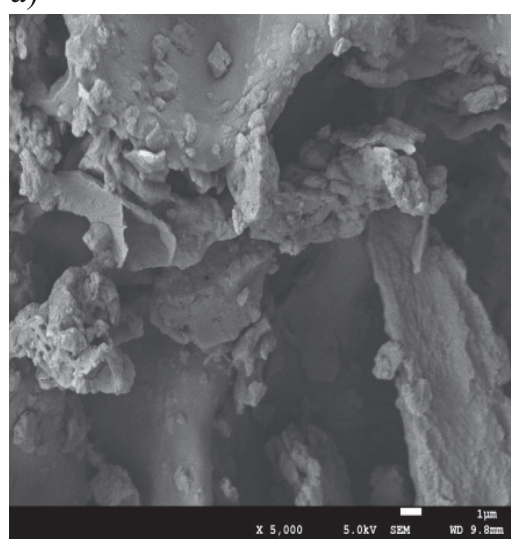

b)

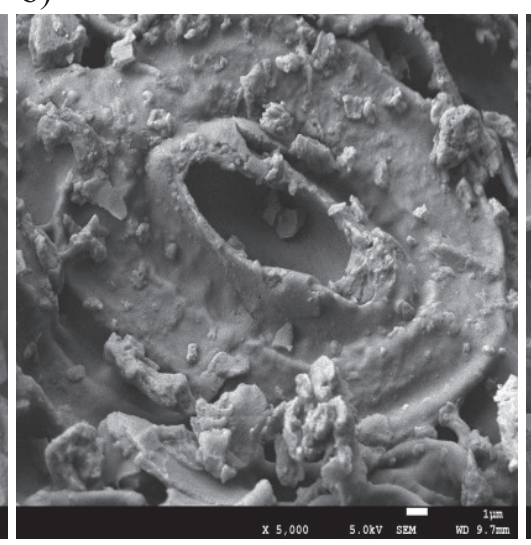

c)

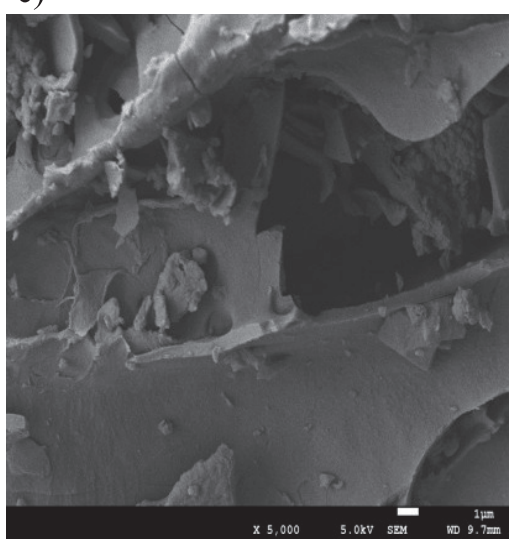

Fig. 1. SEM images of different biochars: a) BC400, b) BC500, c) BC600 (The treatment codes represent biochars made from tea residue. The figure 400, 500 or 600 represents the corresponding pyrolysis temperature). 


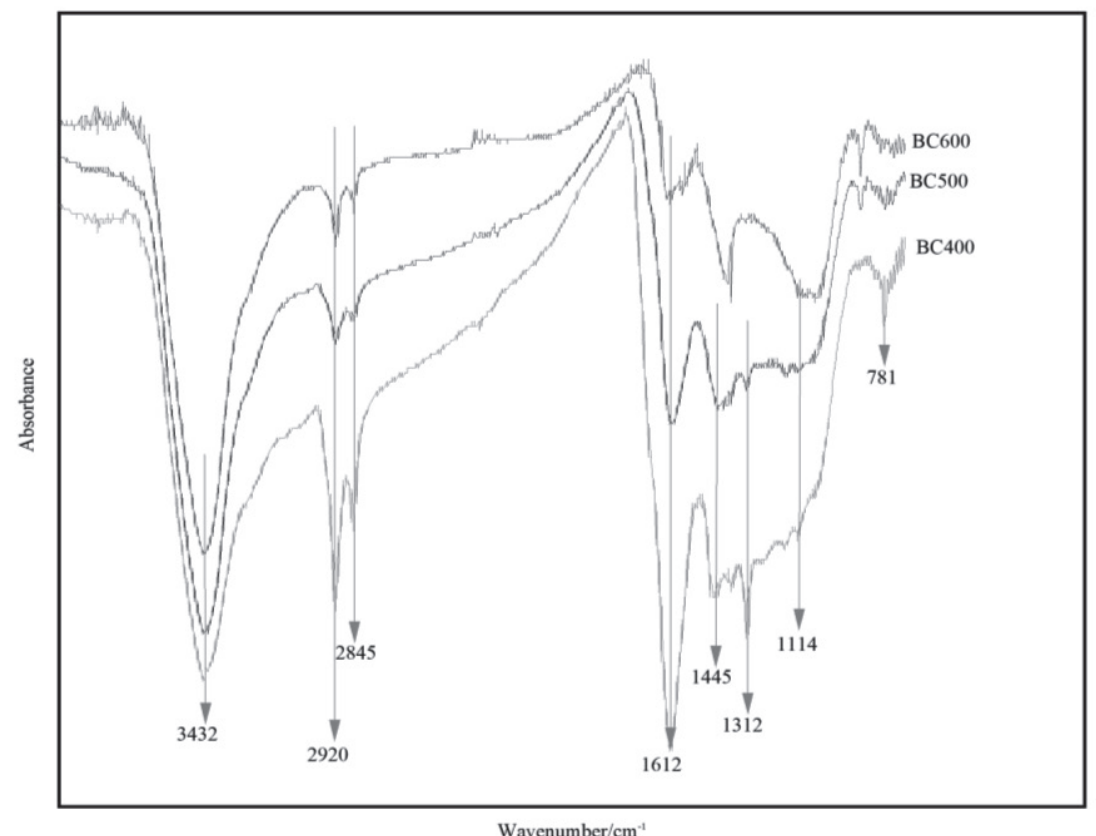

Fig. 2. The FTIR spectra of biochar at different pyrolysis temperatures.

\section{P Adsorption Capacity of Biochar}

Adsorption of phosphorus (P) in soil from biochar depends on the source of the biochars raw materials [30], the pyrolysis temperature of the biochar, and the amount of biochar added to soil. The $\mathrm{P}$ adsorption isotherms of the tea garden soil with biochars produced at different pyrolysis temperatures are shown in Fig. 3. The variation trend of soil adsorption isotherms of different treatment temperatures were consistent based on the percentage of biochar added to soil: the maximum adsorption amount of $\mathrm{P}$ in soils decreased in the following order of biochar to soil percentages for biochar produced at all temperatures: $1.0 \%>0.5 \%>0.25 \%>\mathrm{CK}>2 \%$. The adsorption capacity increased with increasing $\mathrm{P}$ concentration in the equilibrium solution. With increasing $\mathrm{P}$ concentration in the equilibrium solution, the adsorption capacity of phosphorus initially increased, and then tended to stabilize. Under high phosphorus concentration conditions, when the addition of biochar to soil was $1.0 \%$, the effect on adsorption of phosphorus in soil was the most significant, and the maximum adsorption capacity $\mathrm{Q}_{\max }$ was $1502.11 \mathrm{mg} / \mathrm{g}$. Under different pyrolysis temperatures (BC400, BC500 or BC600), when the carbon was added to soil in a $1.0 \%$ mix, the maximum adsorption of $\mathrm{P} \mathrm{Q}_{\max }$ in soil increased by $314.36 \mathrm{mg} / \mathrm{g}$ for $\mathrm{BC} 400,260.32 \mathrm{mg} / \mathrm{g}$ for $\mathrm{BC} 500$ and $87.43 \mathrm{mg} / \mathrm{g}$ for BC600 compared with CK; When the addition of biochar increased to soil increased to $2.0 \%$, the maximum adsorption capacity $\mathrm{Q}_{\max }$ decreased by $4.08 \mathrm{mg} / \mathrm{g}$ for $\mathrm{BC} 400,44.96 \mathrm{mg} / \mathrm{g}$ for $\mathrm{BC} 500$ and $128.93 \mathrm{mg} / \mathrm{g}$ for BC600 compared with $\mathrm{CK}$. The results showed that the addition ratio of biochar affected $\mathrm{P}$ adsorption, and the greatest increase in adsorption was observed when the addition ratio of biochar was $1.0 \%$. As shown in Fig. 3, the maximum adsorption amount of $\mathrm{P}$ in soils decreased in the following order: $\mathrm{BC} 400>\mathrm{BC} 500>\mathrm{BC} 600$, indicating that the pyrolysis temperature can significantly affect the adsorption of P. To further explore the effect of tea residue biochar prepared at different pyrolysis temperatures on the adsorption mechanism of $\mathrm{P}$, the Langmuir equation and Freundlich equations were used to fit the isothermal adsorption process. The Langmuir equation refers to a singlelayer surface adsorption process [31]. The Freundlich adsorption model is used to describe the chemisorption behavior between both monolayers [32] and multilayers [33], the empirical constant $\mathrm{n}$ can indicate the strength of adsorption performance. When $1 / \mathrm{n}$ is less than 1, the adsorption process is easier [34]. Fitting the results of the Freundlich equation showed that the correlation coefficients were $0.92<\mathrm{R}^{2}<0.98$, which was an extremely significant correlation (Table 2). This further indicated that the Langmuir equation and Freundlich equation were suitable for the isothermal adsorption performance fitting of biochar for $\mathrm{P}$ in this study. $\mathrm{K}_{\mathrm{L}}$ is the intensity factor of soil $\mathrm{P}$ adsorption [35], which generally indicates the affinity of $P$ for soil colloids. The higher the $K_{I}$ value is, the higher the $P$ adsorption intensity is [36]. Among the treatments with different pyrolysis temperatures, the $\mathrm{K}_{\mathrm{L}}$ value of the mixed tea garden soil treated with $\mathrm{BC} 400$ was the largest, which indicated that the adsorption capacity of the biochar at this pyrolysis temperature was the strongest, and the adsorbed $\mathrm{P}$ was stable and not easy to be desorbed.

In this study, the difference of phosphorus adsorption capacity of soil under the action of biomass 

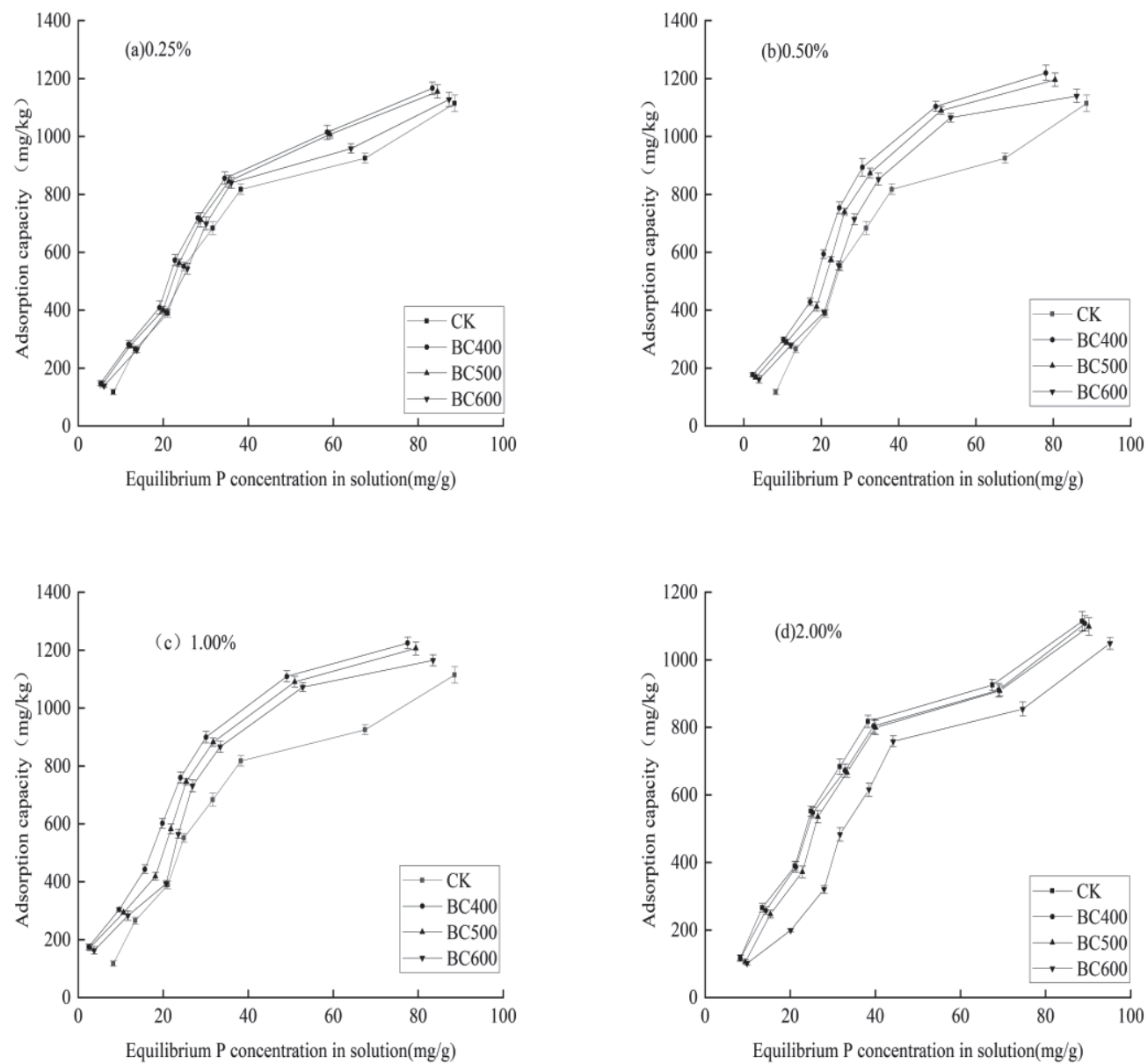

Fig. 3. Adsorption isotherms of different pyrolytic biochar in soil. Error bars represent standard error of triplicate samples (The figure $0.25 \%, 0.50 \%, 1.00 \%$ or $2.00 \%$ represents the addition ratio of biochar).

carbon at different pyrolysis temperatures is $\mathrm{BC} 400$ $>$ BC500, BC600. According to the SEM analysis, when the pyrolysis temperature of biochar was $500^{\circ} \mathrm{C}$ and $600^{\circ} \mathrm{C}$, the structure of biochar was broken and the $\mathrm{P}$ adsorption capacity of soil was less than that of biochar at $400^{\circ} \mathrm{C}$, indicating that the structure of the biomass was the main factor affecting $\mathrm{P}$ adsorption in soil. The results of this study are consistent with the results of Eduah J.O. et al. [37] on three types of soil improvement by biochar produced at different pyrolysis temperatures. The reason for this phenomenon may be that with the increase in pyrolysis temperature, it is difficult for the biochar to maintain its original internal structure, and it begins to fracture, thus reducing the sites of $\mathrm{P}$ adsorption on the soil surface and the total amount of $\mathrm{P}$ adsorption. As shown in Table 2, when the addition of biochar to soil was $1.0 \%$, the adsorption capacity of $\mathrm{P}$ was the largest. When the addition of biochar increased to $2.0 \%$, the adsorption capacity of soil was lower than that of CK. The results of Liu Z. et al. [38] and Mahmoud E. et al. [39] were consistent with the experiment, the content of available $\mathrm{P}$ in soil increased with an increase in biochar content, and the adsorption capacity of $\mathrm{P}$ in soil decreased accordingly.
The reason for this phenomenon may be that biochar is similar to lime. When a lower proportion of biochar is added to the soil, the modification of acidic soil by biochar leads to the precipitation of activated iron and activated aluminum with an increase in $\mathrm{pH}$ [40]. The newly precipitated polymers provide $\mathrm{P}$ adsorption sites in the soil, thus increasing the amount of $\mathrm{P}$ adsorption in the soil; organic anions and carbonates are the main forms of alkaline substances in biochar [41], and when the proportion of biochar increases to a certain extent, the organic anions provided by the biochar may compete with phosphate for the adsorption sites of the soil colloids. At the same time, biochar itself carries $\mathrm{P}$, which is released after entering the soil, and so a higher proportion of biochar may hinder the adsorption of $\mathrm{P}$.

\section{P Desorption Capacity of Biochar}

As an indicator of the adsorption strength, the desorption rate can reflect the firm degree of the combination of colloidal surface active adsorption sites and adsorbents [42]. As shown in Table 3, under different treatments (initial solution concentrations 
Table 2. Isotherm parameters for the adsorption of phosphate on biochar.

\begin{tabular}{|c|c|c|c|c|c|c|c|}
\hline \multirow[b]{2}{*}{ Biochar sample } & \multirow{2}{*}{$\begin{array}{c}\text { The addition ratio } \\
\text { of biochar } / \%\end{array}$} & \multicolumn{3}{|c|}{ Langmuir model } & \multicolumn{3}{|c|}{ Freundlich model } \\
\hline & & $\begin{array}{c}\mathrm{Q}_{\max } \\
(\mathrm{mg} / \mathrm{g})\end{array}$ & $\begin{array}{c}\mathrm{K}_{\mathrm{L}} \\
(\mathrm{L} / \mathrm{mg})\end{array}$ & $\mathrm{R}^{2}$ & $1 / \mathrm{n}$ & $\mathrm{K}_{\mathrm{F}}$ & $\mathrm{R}^{2}$ \\
\hline CK & 0 & 1187.75 & 0.00199 & 0.982 & 0.656 & 61.112 & 0.924 \\
\hline \multirow{4}{*}{$\mathrm{BC} 400$} & 0.25 & 1359.58 & 0.00494 & 0.984 & 0.625 & 78.277 & 0.981 \\
\hline & 0.50 & 1441.76 & 0.00576 & 0.965 & 0.580 & 105.129 & 0.971 \\
\hline & 1.00 & 1502.11 & 0.01028 & 0.975 & 0.564 & 114.003 & 0.979 \\
\hline & 2.00 & 1183.67 & 0.00193 & 0.983 & 0.669 & 56.749 & 0.983 \\
\hline \multirow{4}{*}{ BC500 } & 0.25 & 1346.97 & 0.00408 & 0.983 & 0.639 & 72.294 & 0.980 \\
\hline & 0.50 & 1428.15 & 0.00427 & 0.964 & 0.610 & 89.525 & 0.963 \\
\hline & 1.00 & 1448.07 & 0.00547 & 0.965 & 0.596 & 95.931 & 0.966 \\
\hline & 2.00 & 1142.79 & 0.00078 & 0.982 & 0.703 & 48.379 & 0.981 \\
\hline \multirow{4}{*}{ BC600 } & 0.25 & 1215.02 & 0.00196 & 0.976 & 0.640 & 68.830 & 0.972 \\
\hline & 0.50 & 1325.43 & 0.00222 & 0.962 & 0.617 & 80.456 & 0.952 \\
\hline & 1.00 & 1354.47 & 0.00263 & 0.956 & 0.613 & 83.653 & 0.950 \\
\hline & 2.00 & 1058.82 & 0.00070 & 0.971 & 0.803 & 27.977 & 0.965 \\
\hline
\end{tabular}

of $20 \mathrm{mg} / \mathrm{L}, 100 \mathrm{mg} / \mathrm{L}$ and $200 \mathrm{mg} / \mathrm{L}$ ), the desorption rate of $\mathrm{P}$ to soil increased with an increase in initial $\mathrm{P}$ solution concentration, and the maximum desorption of $\mathrm{P}$ to soil decreased in the following order: $200 \mathrm{mg} / \mathrm{L}>100 \mathrm{mg} / \mathrm{L}>20 \mathrm{mg} / \mathrm{L}$. When the addition of $\mathrm{BC} 400$ was at $1.0 \%$ and the initial $\mathrm{P}$ concentration was $20 \mathrm{mg} / \mathrm{L}$, the desorption rate was $15.23 \%$, when the initial P concentration was $100 \mathrm{mg} / \mathrm{L}$ or $200 \mathrm{mg} / \mathrm{L}$, the desorption rates were $19.63 \%$ and $27.19 \%$, respectively. On comparing biochar produced under different pyrolysis temperatures, the maximum desorption ability of $\mathrm{P}$ in soils was found to decrease

Table 3. Effect of biochar on $\mathrm{P}$ desorption rate at different temperatures.

\begin{tabular}{|c|c|c|c|c|}
\hline Initial $\mathrm{P}$ concentration in solution $(\mathrm{mg} / \mathrm{L})$ & Biochar amendment rate $(\%)$ & $\mathrm{BC} 400(\%)$ & BC500 (\%) & BC600 (\%) \\
\hline \multirow{5}{*}{20} & 0.00 & $38.45 \pm 0.22 \mathrm{a}$ & $38.45 \pm 0.22 \mathrm{a}$ & $38.45 \pm 0.22 \mathrm{a}$ \\
\hline & 0.25 & $22.02 \pm 0.05 \mathrm{c}$ & $26.15 \pm 0.24 b$ & $32.86 \pm 0.35 \mathrm{a}$ \\
\hline & 0.50 & $17.35 \pm 0.04 \mathrm{c}$ & $21.77 \pm 0.05 b$ & $27.00 \pm 0.04 \mathrm{a}$ \\
\hline & 1.00 & $15.23 \pm 0.28 \mathrm{c}$ & $20.87 \pm 0.07 \mathrm{~b}$ & $25.41 \pm 0.08 \mathrm{a}$ \\
\hline & 2.00 & $40.77 \pm 0.4 \mathrm{~b}$ & $41.09 \pm 0.26 \mathrm{~b}$ & $42.24 \pm 0.07 \mathrm{a}$ \\
\hline \multirow{5}{*}{100} & 0.00 & $48.16 \pm 0.22 \mathrm{a}$ & $48.16 \pm 0.22 \mathrm{a}$ & $48.16 \pm 0.22 \mathrm{a}$ \\
\hline & 0.25 & $27.90 \pm 0.07 \mathrm{c}$ & $28.03 \pm 0.04 \mathrm{~b}$ & $29.64 \pm 0.05 a$ \\
\hline & 0.50 & $22.04 \pm 0.2 \mathrm{c}$ & $24.19 \pm 0.05 b$ & $27.84 \pm 0.06 \mathrm{a}$ \\
\hline & 1.00 & $19.63 \pm 0.05 \mathrm{c}$ & $22.71 \pm 0.04 b$ & $23.19 \pm 0.04 \mathrm{a}$ \\
\hline & 2.00 & $45.94 \pm 0.2 \mathrm{~b}$ & $46.24 \pm 0.13 b$ & $47.30 \pm 0.04 \mathrm{a}$ \\
\hline \multirow{5}{*}{200} & 0.00 & $52.39 \pm 0.24 \mathrm{a}$ & $52.39 \pm 0.24 \mathrm{a}$ & $52.39 \pm 0.24 \mathrm{a}$ \\
\hline & 0.25 & $41.82 \pm 0.08 \mathrm{c}$ & $42.35 \pm 0.04 b$ & $43.68 \pm 0.06 \mathrm{a}$ \\
\hline & 0.50 & $37.25 \pm 0.17 \mathrm{c}$ & $38.26 \pm 0.02 b$ & $39.31 \pm 0.03 \mathrm{a}$ \\
\hline & 1.00 & $27.19 \pm 0.09 \mathrm{c}$ & $29.85 \pm 0.04 b$ & $32.30 \pm 0.04 \mathrm{a}$ \\
\hline & 2.00 & $53.16 \pm 0.04 \mathrm{c}$ & $53.64 \pm 0.07 \mathrm{~b}$ & $55.36 \pm 0.04 \mathrm{a}$ \\
\hline
\end{tabular}

Note: The experimental results were indicated as mean \pm standard deviation. Different lowercase letters in the same column in the table indicate significant differences among treatments $(P<0.05)$. 
Table 4. Thermodynamic parameters of $\mathrm{P}$ adsorption in soil.

\begin{tabular}{|c|c|c|c|c|c|c|c|c|c|c|c|}
\hline \multirow[b]{2}{*}{ Sample } & \multirow{2}{*}{$\begin{array}{c}\mathrm{T} \\
(\mathrm{K})\end{array}$} & \multicolumn{3}{|c|}{ Langmuir model } & \multicolumn{3}{|c|}{ Freundlich model } & \multirow{2}{*}{$\frac{\mathrm{Q}_{\mathrm{m}}}{(\mathrm{J} / \mathrm{mol})}$} & \multirow{2}{*}{$\frac{\Delta G}{(\mathrm{KJ} / \mathrm{mol})}$} & \multirow{2}{*}{$\frac{\Delta H}{(\mathrm{KJ} / \mathrm{mol})}$} & \multirow{2}{*}{$\frac{\Delta S}{(\mathrm{KJ} / \mathrm{mol} \cdot \mathrm{K})}$} \\
\hline & & $\begin{array}{c}\mathrm{Q}_{\max } \\
(\mathrm{mg} / \mathrm{g})\end{array}$ & $\begin{array}{c}\mathrm{K}_{\mathrm{L}} \\
(\mathrm{L} / \mathrm{mg})\end{array}$ & $\mathrm{R}^{2}$ & $1 / \mathrm{n}$ & $\mathrm{K}_{\mathrm{F}}$ & $\mathrm{R}^{2}$ & & & & \\
\hline \multirow{3}{*}{$\begin{array}{c}1.0 \% \\
\text { BC400 }\end{array}$} & 288 & 1280.3 & 0.008 & 0.96 & 0.69 & 51.7 & 0.95 & 3467.9 & -13.398 & \multirow{3}{*}{35.71} & \multirow{3}{*}{0.17} \\
\hline & 298 & 1425.7 & 0.034 & 0.98 & 0.62 & 86.4 & 0.98 & 3994.2 & -15.136 & & \\
\hline & 308 & 1613.0 & 0.184 & 0.98 & 0.56 & 136.2 & 0.98 & 4555.9 & -16.809 & & \\
\hline
\end{tabular}

in the following order: BC600 $>$ BC500 $>$ BC400. The higher the temperature of biochar preparation, the stronger the $\mathrm{P}$ desorption capacity of the soil, which is consistent with the $\mathrm{P}$ adsorption capacity of biochar produced at different pyrolysis temperatures. The results showed that the maximum desorption ability of $\mathrm{P}$ in soils decreased in the following order: $2.0 \%>\mathrm{CK}>0.25 \%>0.5 \%>1.0 \%$, which indicated that adding a certain amount of biochar to soil could reduce the leaching of $\mathrm{P}$ and inhibit the desorption of $\mathrm{P}$, but adding too much biochar could promote the desorption of P. In this study, the Langmuir and Freundlich equations fit the $\mathrm{P}$ adsorption behavior of soil under the condition of biochar addition, which shows that when the proportion of biochar added is within a certain range $(0.25 \%-0.5 \%)$, the $\mathrm{P}$ adsorption capacity of soil increases with increase in biochar addition.

Carbon adsorbed on biomass can not be completely desorbed, which is called desorption lag phenomenon, which generally exists in the process of soil pesticide/ fertilizer interaction. In this study, the application of tea residue biochar significantly reduced the phosphorus desorption of tea garden soil, which is mainly due to the strong adsorption capacity of biochar, which can slow down the desorption or isolation of compounds and produce the lag phenomenon of absorption. A possible reason for this phenomenon is that when the concentration of $\mathrm{P}$ solution is low, the adsorption sites on the surface of biochar are relatively sufficient, and the adsorbed $\mathrm{P}$ is difficult to desorb. When the concentration of $\mathrm{P}$ solution is gradually increased, the $\mathrm{P}$ on the adsorption sites is gradually saturated, the adsorption capacity will be low, and the $\mathrm{P}$ adsorbed in other ways is easily desorbed. In the high concentration $\mathrm{P}$ solution, the higher the $\mathrm{P}$ saturation, the stronger the desorption capacity of $\mathrm{P}$, and the greater the leaching risk of adsorbed $\mathrm{P}$ in the soil. In addition, the parameters calculated by the Langmuir model also verified this result. When the proportion of biochar added was low, $\mathrm{Q}_{\max }$ increased with an increase in biochar addition, indicating that adding an appropriate amount of biochar can promote the adsorption of $\mathrm{P}$ in soil. At the same time, adding appropriate amount of biochar can reduce the desorption rate of $\mathrm{P}$ and reduce the risk of $\mathrm{P}$ leaching. As tea residue is considered a waste by the beverage industry, it is easy to obtain, and so tea residue biochar has a broad application prospects in improving soil $\mathrm{P}$ fixation.

\section{Effects of Environmental Factors on the Adsorption Behavior of $\mathrm{P}$}

\section{Effect of Temperature}

Temperature is an important factor affecting the characteristics of chemical reactions [43]. Soil ion adsorption is a reaction that is affected by temperature change [44]. In summary, when the addition of biochar was $1.0 \% \mathrm{BC} 400$, the adsorption-desorption effect of soil on $\mathrm{P}$ was the best, therefore, this sample was used to further study the adsorption behavior of phosphorus at different temperatures. The results of the thermodynamic parameters of $\mathrm{P}$ adsorption in soil are shown in Table 4. According to Table 4, the order of $\Delta H$ $\mathrm{P}$ adsorption in soil is $288 \mathrm{~K}>298 \mathrm{~K}>308 \mathrm{~K}$, indicating that $\mathrm{P}$ is easy to be adsorbed when $\mathrm{T}=308 \mathrm{~K}$; The results showed that there were significant differences in the adsorption efficiency of phosphorus in soil under different environmental temperatures. The adsorption capacity of $\mathrm{P}$ in each soil at high temperatures was larger than that at low temperatures. Compared with the maximum adsorption capacity, the maximum adsorption capacity can be increased by $187.3 \mathrm{mg} / \mathrm{kg}$ based on a temperature increase of $10 \mathrm{~K}$.

It can be seen from Table 4 that the increase of temperature promotes the adsorption of phosphorus, indicating that the adsorption of phosphorus by soil is an endothermic process. When the initial concentration of $\mathrm{P}$ solution continued to increase, the adsorption capacity of $\mathrm{P}$ in soil increased and finally stabilized. $\Delta G$ are all negative, which indicates that the adsorption reaction can take the initiative. The lower the free energy, the more favorable the adsorption reaction [45]. A positive value of indicates that the phosphorus adsorption process is endothermic [46]. $\Delta S$ is a measure of disorder or order before and after phosphorus adsorption by soil [47]. The multistage of adsorption energy sites is affected by $\Delta S$ value, which indicates that phosphorus is multi-level adsorption. It can be seen from Table 4 that the binding energy $\mathrm{K}$ value of phosphorus adsorption at high temperature is greater than that at low temperature, indicating that the adsorption strength of phosphorus can be improved by increasing temperature. This is consistent with the determination of adsorption heat $Q_{m}$. The higher the temperature is, the larger the $\mathrm{Q}_{\mathrm{m}}$ value is. At high temperature, the more firmly the soil adsorbs 


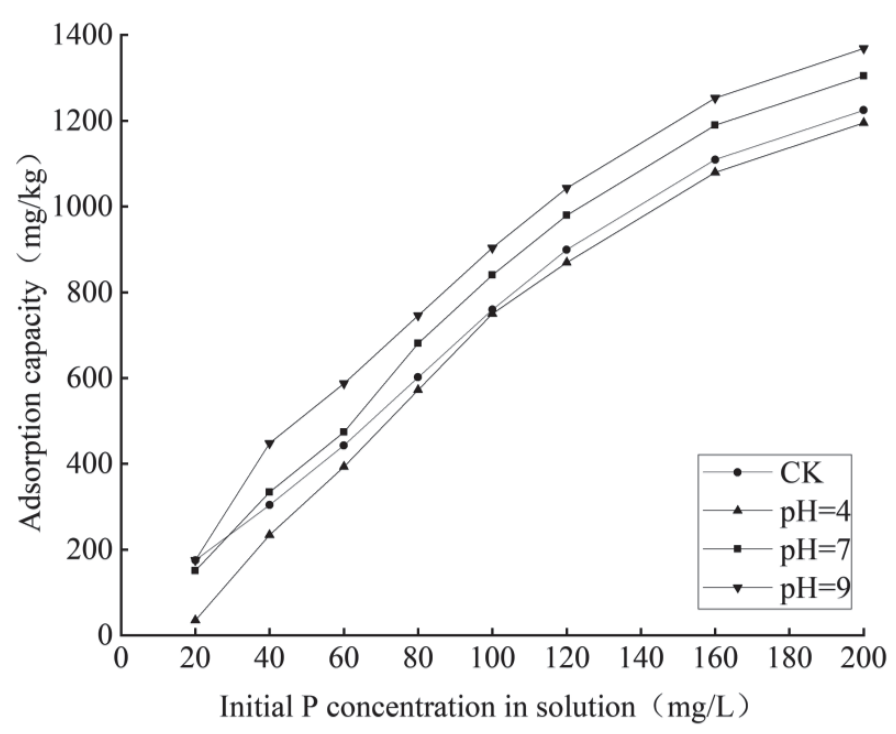

Fig. 4. Effect of $\mathrm{pH}$ of initial Phosphorus Solution on phosphorus adsorption.

Table 5. Correlation analysis of factors affecting soil P adsorption.

\begin{tabular}{|c|c|c|c|c|c|c|c|}
\hline Variation & $\mathrm{C}(\mathrm{mg} / \mathrm{L})$ & $\mathrm{T}(\mathrm{K})$ & $\mathrm{pH}$ & $\mathrm{C} \times \mathrm{T}$ & $\mathrm{C} \times \mathrm{pH}$ & $\mathrm{T} \times \mathrm{pH}$ & $\mathrm{C} \times \mathrm{T} \times \mathrm{pH}$ \\
\hline Adsorption capacity $(\mathrm{mg} / \mathrm{g})$ & $0.993^{* *}$ & $0.987 * *$ & $0.697 *$ & $0.984^{* *}$ & $0.906^{* *}$ & $0.901 * *$ & $0.937 * *$ \\
\hline
\end{tabular}

Note: * and ** respectively showed significant correlation between $P<0.05$ and $P<0.01$.

phosphorus. This is consistent with the previous conclusion, that the adsorption of $\mathrm{P}$ in soil is an endothermic reaction, and the adsorption of $\mathrm{P}$ in soil is positively correlated with the temperature in the environment. In addition, the above characteristics of the endothermic reaction also show that the adsorption process of $\mathrm{P}$ is a chemical reaction rather than a physical adsorption [48].

\section{Effect of $p H$}

When the addition of biochar was $1.0 \% \mathrm{BC} 400$, the results of $\mathrm{P}$ adsorption behavior of the initial solution change depending on the $\mathrm{pH}$, as shown in Fig. 4. The of $\mathrm{P}$ adsorption increased in the following order of $\mathrm{pH}: 4<7<9$. Compared to $\mathrm{CK}$ without biomass carbon, the maximum adsorption capacity of $\mathrm{P}$ increased by $341.45 \mathrm{mg} / \mathrm{kg}$ at $\mathrm{pH}$ of $4,794.17 \mathrm{mg} / \mathrm{kgat} \mathrm{pH}$ of 7 , and $1069.35 \mathrm{mg} / \mathrm{kg}$ at $\mathrm{pH}$ of 9 . the total maximum adsorption capacity of $\mathrm{P}$ was $2257.10 \mathrm{mg} / \mathrm{kg}$ at $\mathrm{pH}$ of 9 . It indicates that the initial $\mathrm{P}$ solution significantly promoted the adsorption of $\mathrm{P}$ at different $\mathrm{pH}$ values.

In this study, the change in the $\mathrm{pH}$ value of the initial $\mathrm{P}$ solution concentration has an effect on soil $\mathrm{P}$ availability, in that reducing $\mathrm{pH}$ can increase the adsorption of $\mathrm{P}$ by organic coordination on soil particles. Ajmal Z. et al. [49] studied the adsorption, desorption and regeneration of phosphate, which showed that the adsorption capacity of phosphate increased with an increase in $\mathrm{pH}$, this finding was supported by the results of this experiment. The reason for this phenomenon may be that the increase of $\mathrm{pH}$ promotes formation of hydroxide precipitation from iron and aluminum oxides [50]. At the same time, the single $\mathrm{P}$ coordination complex rapidly transforms to the double $\mathrm{P}$ coordination complex, which reduces the concentration of free iron and aluminum oxides in acidic soil, thus reducing the adsorption of $\mathrm{P}$. Therefore, increasing the $\mathrm{pH}$ of the initial $\mathrm{P}$ solution can increase the adsorption capacity of soil. To further explore the $\mathrm{P}$ adsorption effect of soil under different environmental conditions, a correlation analysis of the environmental factors affecting its adsorption capacity was carried out. As shown in Table 5 the initial concentration and temperature had extremely significant effects on the process of $\mathrm{P}$ adsorption $(\mathrm{P}<0.01)$. The $\mathrm{pH}$ of the solution had a significant effect on the process of $\mathrm{P}$ adsorption $(\mathrm{P}<0.05)$. The combined effect of these variables on $\mathrm{P}$ adsorption in soil is extremely significant. This confirmed that the initial concentration, temperature, and $\mathrm{pH}$ played an important role in the process of $\mathrm{P}$ adsorption.

\section{Conclusions}

In this study, after tea residue biomass carbon was input into soil, it could increase the adsorption of phosphorus and reduce the desorption of phosphorus rate. The adsorption desorption characteristics of tea 
residue biochar on tea garden soil were significantly different at different pyrolysis temperatures, which showed that $\mathrm{BC} 400>\mathrm{BC} 500>\mathrm{BC} 600$. while the desorption rate was on the contrary, $\mathrm{BC} 400<\mathrm{BC} 500<\mathrm{BC} 600$.

Tea residue biochar promoted the adsorption process of $\mathrm{P}$ in soil when the proportion of biochar was within a certain range in the soil $(0.25 \%-1.0 \%)$. In addition, the Langmuir equation can describe the process of phosphorus adsorption $\left(0.95<\mathrm{R}^{2}<0.98\right)$. When the proportion of biochar was within a certain range $(0.25 \%-1.0 \%)$, the application of tea residue biochar to soil significantly reduced the soil $\mathrm{P}$ desorption, mainly due to the strong adsorption capacity of the biochar, which could slow down the desorption of compounds.

Environmental conditions strongly affected the adsorption of phosphorus in the soil. The adsorption of phosphorus in soil is spontaneous and is positively correlated with the temperature of the environment and the $\mathrm{pH}$ of the initial solution. Under the combined action of concentration, temperature, and $\mathrm{pH}$, the correlation is 0.937. Therefore, adding an appropriate amount of tea residue biochar to the soil was found to be an effective approach to realize the utilization of resources, economy and environment.

\section{Acknowledgments}

We are grateful to National Natural Science Foundation of China (No. 51578002), Natural Science Foundation of Anhui Province, China (No. KJ2019ZD54; No. KJ2019A0754) for their financial support.

\section{Conflict of Interest}

The authors declare no conflict of interest.

\section{References}

1. MIDGLEY D.J., LETCHER P.M., MCGEE P.A. Access t o organic and insoluble sources of phosphorus varies among soil Chytridiomycota. Arch. Microbiol. 186 (3), 211, 2006.

2. SEGUEL A., CUMMING J.R., KLUGH-STEWART K., CORNEJO P., BORIE F. The role of arbuscular mycorrhizas in decreasing aluminium phytotoxicity in acidic soils: a review. Mycorrhiza. 23 (3) 167, 2013.

3. ZHANG J., TANG L., TANG W., ZHONG Y., LIANG J. Removal and recovery of phosphorus from low-strength wastewaters by flow-electrode capacitive deionization. Sep. Purif. Technol. 237, 116322, 2019.

4. SUN T., DENG L., FEI K., ZHANG L., FAN X. Correction to: Characteristics of phosphorus adsorption and desorption in erosive weathered granite area and effects of soil properties. Environ. Sci. Pollut. Res. 27 (23), 2020.
5. KRAVKAZ-KUSCU., IS., SARIYILDIZ., CETIN., YIGIT., SEVIK., SAVACI. Evaluation of the soil properties and primary forest tree species in Taskopru (kastamonu) district. Fresen Environ. Bull. 27 (3), 1613, 2018.

6. CETIN M., SEVIK H., SAAT A. Indoor air quality: the samples of safranbolu bulak mencilis cave. Fresen Environ. Bull. 26 (10), 5965, 2017.

7. VAROL T., EMIR T., AKGUL M., OZEL H.B., ACAR H.H., CETIN M. Impacts of small-scale mechanized logging equipment on soil compaction in forests. J Soil Sci. Plant Nutr. 20 (3), 953, 2020.

8. CETIN M. A change in the amount of $\mathrm{CO}_{2}$ at the center of the examination halls: case study of turkey. Studies on Ethno-Medicine. 10 (2), 146, 2016.

9. TURKYILMAZ., AYDIN., SEVIK., HAKAN., CETIN., MEHMET., SALEH., ELNAJI A., AHMAIDA. Changes in heavy metal accumulation depending on traffic density in some landscape plants. Pol. J. Environ. Stud. 27 (5), 2018.

10. KUSCU., IS KRAVKAZ., CETIN., MEHMET., YIGIT. NURCAN., SAVACI., GAMZE., SEVIK., HAKAN. Relationship between enzyme activity (urease-catalase) and nutrient element in soil use. Pol. J. Environ. Stud. 27 (5), 2018.

11. CETIN M. Landscape Engineering, Protecting Soil, and Runoff Storm Water. Advances in Landscape Architecture. 2013.

12. ENDERS A., HANLEY K., WHITMAN T., JOSEPH S., LEHMANN J. Characterization of biochars to evaluate recalcitrance and agronomic performance. Bioresour. Technol. 114, 644, 2012

13. SHI Q., ZHANG H., SHAHAB A., ZENG H., ULLAH H. Efficient performance of magnesium oxide loaded biochar for the significant removal of $\mathrm{Pb}^{2+}$ and $\mathrm{Cd}^{2+}$ from aqueous solution. Ecotoxicol. Environ. Saf. 221 (15), 112426, 2021.

14. CETIN M., SEVIK H. Change of air quality in kastamonu city in terms of particulate matter and $\mathrm{CO}_{2}$ amount. Oxid. Commun. 39(4), 3394, 2016.

15. CETIN., SEVIK. Measuring the impact of selected plants on indoor $\mathrm{CO}_{2}$ concentrations. Pol. J. Environ. Stud. 25(3), 973, 2016.

16. WANG C., LI L., SHI J., JIN H. Biochar production by coconut shell gasification in supercritical water and evolution of its porous structure. J. of Anal. Appl. Pyrolysis. 156 (57), 105151, 2021.

17. MURTAZA G., USMAN M., AHMED Z., SHABBIR R.N., ULLAH Z. EQA -International Journal of Environmental Quality Molecular understanding of biochar aging on their properties and environmental significances. J. Environ. Qual. 43, 30, 2021.

18. QUE W., JIANG L., WANG C., LIU Y., ZENG Z.W., WANG X.H., NING Q.M., LIU S.H., ZHANG P., LIU S. Influence of sodium dodecyl sulfate coating on adsorption of methylene blue by biochar from aqueous solution. J. Environ. Sci. 2018.

19. HA NN ET G., SINGH K., FIDELIS C., FARRAR M.B. MUQADDAS B., BAI S.H. Effects of biochar, compost, and biochar-compost on soil total nitrogen and available phosphorus concentrations in a corn field in Papua New Guinea. Environ. Sci. Pollut. Res. 28 (21), 27411, 2021.

20. XU G., SUN J.N., SHAO H.B., CHANG S.X. Biochar had effects on phosphorus sorption and desorption in three soils with differing acidity. Ecol. Eng. 62, 54, 2014.

21. GU S., GRUAU G., DUPAS R., RUMPEL C., CREME A., FOVET O., GASCUEL ODOUX C., JEANNEAU 
L., HUMBERT G., PETITJEAN P. Release of dissolved phosphorus from riparian wetlands: Evidence for complex interactions among hydroclimate variability, topography and soil properties. Sci. Total Environ. 598, 421, 2017.

22. RASHMI I., JHA P., BISWAS A.K. Phosphorus Sorption and Desorption in Soils Amended with Subabul Biochar. Agric. Res. 9 (2), 2019.

23. MUKHERJEE S., MAVI M.S., SINGH J. Differential response of biochar derived from rice-residue waste on phosphorus availability in soils with dissimilar $\mathrm{pH}$. Int. J. Environ. Sci. Technol. 17 (7), 2019.

24. YING Y., GAO B., ZHANG M., INYANG M., ZIMMERMAN A.R Effect of biochar amendment on sorption and leaching of nitrate, ammonium, and phosphate in a sandy soil. Chemosphere. 89 (11), 1467, 2012.

25. MANOLIKAKI I.I., MANGOLIS A., DIAMADOPOULOS E. The impact of biochars prepared from agricultural residues on phosphorus release and availability in two fertile soils. J. Environ. Manage. 181, 536, 2016.

26. HUA F., ZHOU P., LIU P.P., BAO G. Rat plasma protein binding of kaempferol-3-O-rutinoside from Lu'an GuaPian tea and its anti-inflammatory mechanism for cardiovascular protection. J. Food Biochem. 45 (7), 2021.

27. VAROL T., OZEL H.B., ERTUGRUL M., EMIR T., TUNAY M., CETIN M., SEVIK M. Prediction of soilbearing capacity on forest roads by statistical approaches. Environ. Monit. Assess. 193 (8), 1, 2021.

28. JACKSON M.L. Soil Chemical Analysis. Soil Sci. 85 (22), 288, 1973.

29. LUIZA USEVIIUT., BALTRNAIT-GEDIEN E. Modelling of a Capillary Rise Height of Biochar by Modified LucasWashburn Equation, 2021.

30. FONSECA A.A., SANTOS D.A., RR PASSOS, ANDRADE F.V., RANGEL O. Phosphorus availability and grass growth in biochar-odified acid soil: a study excluding the effects of soil pH. Soil Use Manage. 2020.

31. ABE I., FUKUHARA T., MARUYAMA J., TATSUMOTO H., IWASAKI S. Preparation of carbonaceous adsorbents for removal of chloroform from drinking water. Carbon. 39 (7), 1069, 2001.

32. JIANG Z., LI N., LI P Y., LIU B., JIN T. One-Step Preparation of Chitosan-Based Magnetic Adsorbent and Its Application to the Adsorption of Inorganic Arsenic in Water. Molecules. 26 (6), 2021.

33. CHEN J., HU H., YANG J., XUE H., LIU Y. Removal behaviors and mechanisms for series of azo dye wastewater by novel nano constructed macro-architectures material. Bioresour. Technol. 322, 124556, 2021.

34. JUSOH A.B., CHENG W.H., LOW W.M., A NORA'AINI., NOOR M.J.M.M. Study on the removal of iron and manganese in groundwater by granular activated carbon. Desalination. 182 (1), 347, 2005.

35. NASERI A., BARATI R., RASOULZADEH F., BAHRAM M. Studies on Adsorption of Some Organic Dyes from Aqueous Solution onto Graphene Nanosheets. Iran. J. Chem. Chem. Eng. 34 (1), 51, 2015.

36. PAULINO A.T., BELFIORE L.A., KUBOTA L.T., MUNIZ E.C., ALMEIDA V.C., Tambourgi E.B. Effect of magnetite on the adsorption behavior of $\mathrm{Pb}(\mathrm{II}), \mathrm{Cd}(\mathrm{II})$, and $\mathrm{Cu}(\mathrm{II})$ in chitosan-based hydrogels. Desalination. 275 (1), 187, 2011.

37. EDUAH J.O., NARTEY E.K., ABEKOE M.K., BREUNING-MADSEN H., ANDERSEN M.N. Phosphorus retention and availability in three contrasting soils amended with rice husk and corn cob biochar at varying pyrolysis temperatures. Geoderma. 341, 10, 2019.

38. LIU Z., TANG J., REN X., Schaeffer S.M. Effects of phosphorus modified nZVI-biochar composite on emission of greenhouse gases and changes of microbial community in soil. Environ. Pollut. 274 (5), 116483, 2021.

39. MAHMOUD E., IBRAHIM M., EL-RAHMAN L., KHADER A.A. Effect of biochar with and without phosphorus fertilizers on phosphorus fractions, wheat yield and microbal biomass carbon in alkakine soil, 2018.

40. AMARASIRI S.L., OLSEN S.R. Liming as Related to Solubility of P and Plant Growth in an Acid Tropical Soil. Soil Sci. Soc. Am. J. 37 (5), 716, 1973.

41. JOSEPH S., GRABER E.R., CHIA C., MUNROE P., DONNE S., THOMAS T., NIELSEN S., MARJO C., RUTLIDGE H., PAN G.X. Shifting paradigms: development of high-efficiency biochar fertilizers based on nano-structures and soluble components. Carbon Manage. 4 (3), 323. 2013.

42. PATUREJ J., DUBBELDAM J., ROSTIASHVILI V.G., MILCHEV A., VILGIS T.A. Force spectroscopy of polymer desorption: theory and molecular dynamics simulations. Soft Matter. 10 (16), 2785, 2014.

43. LUO X., ZHANG X., ZHAO L., DONG H. Study on the characteristics of pellet movement under different roasting temperature in hopper. Powder Technol. 386 (1), 2021.

44. CASTALDI P., SILVETTI M., SANTONA L., ENZO S., MELIS P. XRD, FTIR, and Thermal Analysis of Bauxite Ore-Processing Waste (Red Mud) Exchanged with Heavy Metals. Clays Clay Miner. 56 (4), 461, 2008.

45. GRITZNER G. Gibbs free energies of transfer ( $\Delta$ Gotr) for alkali metal ions and tl+. Inorg. Chim. Acta. 24, 5, 1977.

46. SR A., AR B., MNZ C., SSS D., SA A. Synthesis and characterization of $\mathrm{MgO}$ supported $\mathrm{Fe}-\mathrm{Co}-\mathrm{Mn}$ nanoparticles with exceptionally high adsorption capacity for Rhodamine B dye-Science Direct. J. Mater. Res. Technol. 8 (5), 3800, 2019.

47. BHATTACHARYYA D., DAWLATY J.M. Teaching Entropy from Phase Space Perspective: Connecting the Statistical and Thermodynamic Views Using a Simple One-Dimensional Model. J. Chem. Educ. 96 (10), 2019.

48. YANG X., CHEN X., YANG X. Effect of organic matter on phosphorus adsorption and desorption in a black soil from Northeast China. Soil Tillage Res. 187, 85, 2019.

49. AJMAL Z., MUHMOOD A., USMAN M., KIZITO S., LU J., DONG R., WU S. Phosphate removal from aqueous solution using iron oxides: Adsorption, desorption and regeneration characteristics. J. Colloid Interface Sci. 528, $145,2018$.

50. NAIDU R., BOLAN N.S., KOOKANA R.S., TILLER K.G. Ionic-strength and $\mathrm{pH}$ effects on the sorption of cadmium and the surface charge of soils. Eur. J. Soil Sci. 45 (4), 419, 2010. 
